\title{
Comparison of behavioral and clinical effects of intravenous amitraz or romifidine administration in horses
}

\author{
[Comparação de efeitos comportamentais e clínicos da administração intravenosa de \\ amitraz ou romifidina em eqüinos] \\ M.C. Mendes, R.G. Reis, C.A.A. Valadão, J.A. Marques \\ Faculdade de Ciências Agrárias e Veterinárias - UNESP \\ 14884-900 - Jaboticabal-SP
}

\begin{abstract}
Clinical and behavioral effects of intravenous injection of romifidine $(60 \mathrm{mcg} / \mathrm{kg})$ or amitraz $(0.4 \mathrm{mg} / \mathrm{kg})$ were compared in six horses, over $120 \mathrm{~min}$. Romifidine caused head ptosis (HP), reduced respiratory rate (RR) and ileo-cecal sphincter activity (IC) until 120 minutes; produced posture changes (PC) until 90 minutes, upper eyelid drop (ED) and sedation (SD) until 60 minutes, intestinal motion (IM) reduction and lower lip drop (LD) until 45 minutes. Amitraz reduced heart rate (HR), RR, IM and IC, and promoted HP, $\mathrm{ED}, \mathrm{LD}$, penis drop $(\mathrm{PD})$ and sedation with posture changes until $120 \mathrm{~min}$. At $90 \mathrm{~min}$ amitraz produced $\mathrm{HP}$ and ED more intensively than romifidine. The LD was similar between 45 and 60 minutes. Romifidine produced intense sedation at $10 \mathrm{~min}$ while amitraz sedation was more significant between 90 and 120 minutes. It is concluded that both romifidine and amitraz can produce strong sedation until 60 and 120 minutes, respectively. Though amitraz sedation and posture changes had a later onset related to romifidine, these effects lasted longer.
\end{abstract}

Keywords: horse, amitraz, romifidine, sedation

\section{RESUMO}

Compararam-se os efeitos sedativos e clinicos em seis eqüinos tratados com romifidina (60mcg/kg) ou amitraz $(0,4 \mathrm{mg} / \mathrm{kg})$, pela via intravenosa, durante 120 minutos. A romifidina promoveu ptose da cabeça $(P C)$, reduziu a freqüencia respiratória (FR) e o movimento da válvula íleo-cecal (MC) durante 120 minutos, provocou alteração postural (AP) por 90 minutos, induziu ptose palpebral (PP) e sedação (SD) por 60 minutos, diminuiu a motilidade intestinal (MI) e causou ptose labial (PL) durante 45 minutos. $O$ amitraz reduziu a freqüencia cardíaca (FR), $F R$, MI e MC e provocou PC, PP, PL, prolapso peniano $(P P)$ e sedação com alteração postural por 120 minutos. Aos 90 minutos, o amitraz induziu a $P C$ e a $P P$ mais intensamente que a romifidina; o mesmo ocorreu entre 45 e 60 minutos para PL. A romifidina produziu sedação maior aos 10 minutos; para o amitraz, a sedação foi mais intensa entre 90 e 120 minutos. Conclui-se que a romifidina e o amitraz produzem sedação intensa por 60 e 120 minutos, respectivamente. A sedação e as alterações posturais induzidas pelo amitraz foram de início tardio, porém tiveram maior duração.

Palavras-chave: eqüino, amitraz, romifidina, sedação

Recebido em 11 de maio de 2006

Aceito em 8 de novembro de 2007

Endereço para correspondência (corresponding address)

Rua 7 de Setembro, 2340/82 - 13560-181 - São Carlos, SP

E-mail: marinacmendes@yahoo.com.br 


\section{INTRODUCTION}

Alfa-2 adrenergic receptor agonists (alfa-2 agonists) produce sedation, analgesia and muscle relaxation in a dose-dependent way and can be used as adjutants on general anesthesia in domestic animals, reducing significantly the doses of both the injectable and inhalatory anesthetics. Drugs from this group have affinity and specificity for subtypes of alfa-2 receptors that grant them diverse extent of effects, intensity of sedation and analgesia (Freeman and England, 2000).

Romifidine is an alfa- 2 agonist often used as a sedative causing long-lasting sedative effect (Hamm et al., 1995; Christovão et al., 2006) that promotes hypertension followed by hypotension and bradycardia concurrent with second-degree atrioventricular block (Clarke et al., 1991; Marques et al., 1998).

Amitraz acts on alfa- 2 adrenergic receptors in a competitive and reversible way and with no cumulative effects (Costa et al., 1989). Horses intoxicated by amitraz show sleepiness, depression, ataxia, muscle weakness and colon impactation associated with low intestinal motility (Roberts and Seawright, 1983; Smith, 1994). Intravenous injection of $0.1 \mathrm{mg} / \mathrm{kg}$ amitraz, diluted in dimetilformamide, produces sedation and reduces spontaneous locomotory activity in horses for 120 minutes (Harkins et al., 1997).

Considering that the effects of romifidine in horses mediated by its high specific action on alpha-2 receptors are well known, this study proposed to compare its sedative effects with those produced by amitraz, in order to determine the possibility of using it drug as a sedative drug in horses.

\section{MATERIAL AND METHODS}

This study was carried out in six adult horses, males or females, with ages between three and 10 years, in good clinical condition and with no contact with amitraz for, at least, six months. During one month (adaptation period) the horses were kept on pastures and fed commercial ration twice daily, received water and grass hay ad libitum and were conditioned to the experimental management in stocks. The same horses were used in both treatments. The interval between treatments was at least 15 days. Experimental assays occurred in afternoon periods, in a temperature-controlled room $\left(25 \pm 1^{\circ} \mathrm{C}\right)$ with the horse restrained in a stock.

Sedation and muscle relaxation were quantified by sedation degree (SD), head ptosis (HP), upper eyelid (ED), lower lip (LD) and penis (PD) drops and by posture changes (PC). SD was quantified in scores from 0 to 3 , considering sedation as a loss of relation between the animal and the environment, with the absence or decrease of responsive behaviors to environmental stimulus. PC was determined as any lack of kinesthesis or proprioception and was classified in scores from 0 to 4 . To evaluate the HP, the distance in centimeters between the lower lip and the floor was measured by using a metric scale fixed on the lateral of the stock. These data were converted to a percentage relation between the observed value at the respective moment and the basal value (presented by the horse before receiving the drug). ED and $\mathrm{LD}$ were scored from 0 to 3 , considering the proportion of the ocular globe that was covered by the superior eyelid and the degree of relaxation of the lower lip, respectively. PD was quantified in scores from 0 to 4 , according to the exposed portion of the penis.

Heart rate (HR), respiratory rate (RR), intestinal motion (IM), ileo-cecal sphincter activity (IC) and rectal temperature (RT) were quantified through usual clinical methods.

Basal parameters were evaluated twice, waiting 10 minutes between the two checks (T-10 and T0). Basal values were calculated as the mean value found between these two checks.

Immediately after the second clinical evaluation and local asepsis, romifidine or amitraz was injected in the external jugular vein. The first treatment consisted of all horses receiving $60 \mathrm{mcg} / \mathrm{kg}$ of romifidine ${ }^{1}$. In the second treatment, the same animals received $0.4 \mathrm{mg} / \mathrm{kg}$ of amitraz $^{2}$, prepared in a lipid excipient as described by Farias (2004).

\footnotetext{
${ }^{1}$ Boehringer De Angeli Química e Farmacêutica Ltda. Itapecerica da Serra, SP - Brazil.

${ }^{2}$ Laboratório Sintesul AS. - Pelotas, RS - Brazil.
} 
After drug administration, all parameters were evaluated in 10 minute intervals (T10, T20 and T30) until 30 minutes, in 15 minutes time intervals (T45, T60) until 60 minutes and in 30 minute time intervals (T90, T120) until 120 minutes.

Parametric datum (RT) was analyzed by an oneway ANOVA. Non-parametric data (HR, RR, HP, IC, IM, SD, ED, LD, PC and PD) were submitted to the Kruskal-Wallis test. ANOVA was followed by Dunnett's test in order to compare each time with basal values, with $5 \%$ of significance. Non-parametric data were analyzed by the Mann-Withney's test with $5 \%$ of significance to comparisons between treatments. Similarly, the Student's $t$-test with $5 \%$ of significance was applied to parametric data. Statistical analysis and representative graphs were developed by Microsoft Excel 2000, SigmaPlot 2000 for Windows version 6.00 and SigmaStat for Windows version 1.0.

\section{RESULTS AND DISCUSSION}

Tab. 1 and 2 show the results for PC, ED, LD, PD, IM, IC and RT for both treatments, in all observation moments. Fig. 1.1 to 1.4 show the results for $\mathrm{HP}, \mathrm{SD}, \mathrm{HR}$ and $\mathrm{RR}$.

Table 1. Clinical and behavioral effects observed in horses treated with intravenous romifidine $(60 \mathrm{mcg} / \mathrm{kg})$ or amitraz $(0.4 \mathrm{mg} / \mathrm{kg})$ administration. Basal indicates the mean between the values measured before drug administration. Time T10 to T120 indicate checking at respective moments (in minutes) after drug administration. Data presented as modal values

\begin{tabular}{|c|c|c|c|c|c|c|c|c|c|}
\hline & \multirow[b]{2}{*}{ Group } & \multicolumn{8}{|c|}{ Moment } \\
\hline & & Basal & $\mathrm{T} 10$ & $\mathrm{~T} 20$ & T30 & $\mathrm{T} 45$ & T60 & T90 & $\mathrm{T} 120$ \\
\hline \multirow[t]{2}{*}{ ED } & Amitraz & 0 & $1 *$ & $2 *$ & $2 *$ & $3 *$ & $3 *$ & $2 * \#$ & $2 *$ \\
\hline & Romifidine & 0 & $2 *$ & $2 *$ & $3 *$ & $2 *$ & $2 *$ & $0^{\#}$ & 0 \\
\hline \multirow[t]{2}{*}{ LD } & Amitraz & 0 & $1 *$ & $3 *$ & $3 *$ & $3 * \#$ & $3 * \#$ & $*$ & $2 *$ \\
\hline & Romifidine & 0 & $2 *$ & $2 *$ & $2 *$ & $1 * \#$ & $0^{\#}$ & 0 & 0 \\
\hline \multirow[t]{2}{*}{ PD } & Amitraz & 0 & $1 *$ & $3 *$ & $3 *$ & $3^{*}$ & $3 *$ & $3 * \#$ & $1 *$ \\
\hline & Romifidine & 0 & 0 & 1 & 2 & 0 & 0 & $0^{\#}$ & 0 \\
\hline \multirow[t]{2}{*}{$\mathrm{PC}$} & Amitraz & 0 & 0 *\# & $2^{*}$ & $4^{*}$ & $4 *$ & $4 *$ & $3 *$ & $2 * \#$ \\
\hline & Romifidine & 0 & $4^{* \#}$ & $4 *$ & $4^{*}$ & $3 *$ & $3 *$ & $0^{*}$ & $0^{\#}$ \\
\hline \multirow[t]{2}{*}{ IM } & Amitraz & 2 & 2 & $1^{*}$ & $1 *$ & $1 *$ & $1 *$ & $1 * \#$ & $2 *$ \\
\hline & Romifidine & 2 & $1 *$ & $1 *$ & $1 *$ & $1 *$ & 2 & $2^{\#}$ & 2 \\
\hline
\end{tabular}

ED: upper eyelid drop; LD: lower lip drop; PD: penis drop; PC: posture changes; IM: intestinal motion. *: significant differences comparing to basal values, Dunnett's test $(\mathrm{P} \leq 0.05)$. \#: significant differences between drugs in the particular moment, Mann-Whitney's test $(\mathrm{P} \leq 0.05)$.

Table 2. Clinical effects observed in horses treated with intravenous romifidine $(60 \mathrm{mcg} / \mathrm{kg})$ or amitraz $(0.4 \mathrm{mg} / \mathrm{kg})$ administration. Basal indicates the mean between the values measured before drug administration. Time T10 to T120 indicate checking at respective moments (in minutes) after drug administration. Data presented as mean \pm standard error

\begin{tabular}{|c|c|c|c|c|c|c|c|c|c|}
\hline & \multirow[b]{2}{*}{ Group } & \multicolumn{8}{|c|}{ Moment } \\
\hline & & Basal & $\mathrm{T} 10$ & $\mathrm{~T} 20$ & $\mathrm{~T} 30$ & T45 & T60 & T90 & T120 \\
\hline \multirow[t]{2}{*}{$\mathrm{IC}$} & Amitraz & $2.9 \pm 0.1$ & $2 \pm 0.5^{*}$ & $1 \pm 0.4^{*}$ & $0 \pm 0^{*}$ & $0 \pm 0.1^{*}$ & $1 \pm 0.4^{*}$ & $1 \pm 0.4^{*}$ & $2 \pm 0.5^{*}$ \\
\hline & Romifidine & $2.3 \pm 0.2$ & $0 \pm 0 *$ & $0 \pm 0 *$ & $0 \pm 0.2^{*}$ & $0 \pm 0.1 *$ & $1 \pm 0.4^{*}$ & $1 \pm 0.4^{*}$ & $2 \pm 0.4 *$ \\
\hline \multirow[t]{2}{*}{ RT } & Amitraz & $38.1 \pm 0.1$ & $38.2 \pm 0$ & $38.1 \pm 0.2$ & $38.1 \pm 0.1$ & $38.1 \pm 0.1$ & $38.0 \pm 0.1$ & $38.0 \pm 0.1$ & $37.8 \pm 0.2$ \\
\hline & Romifidine & $38.2 \pm 0.1$ & $38.3 \pm 0.1$ & $38.3 \pm 0.1$ & $38.3 \pm 0.1$ & $38.3 \pm 0.1$ & $38.1 \pm 0$ & $38 \pm 0.1$ & $37.8 \pm 0$ \\
\hline
\end{tabular}

IC: ileo-cecal sphincter activity (movements each 3 minutes). RT: rectal temperature $\left({ }^{\circ} \mathrm{C}\right) .{ }^{*}$ : significant differences comparing to basal values, Dunnett's test $(\mathrm{P} \leq 0.05)$. 


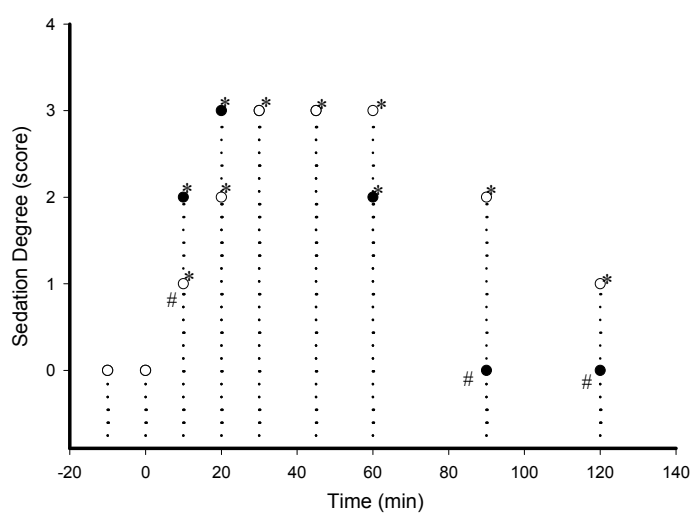

(1)

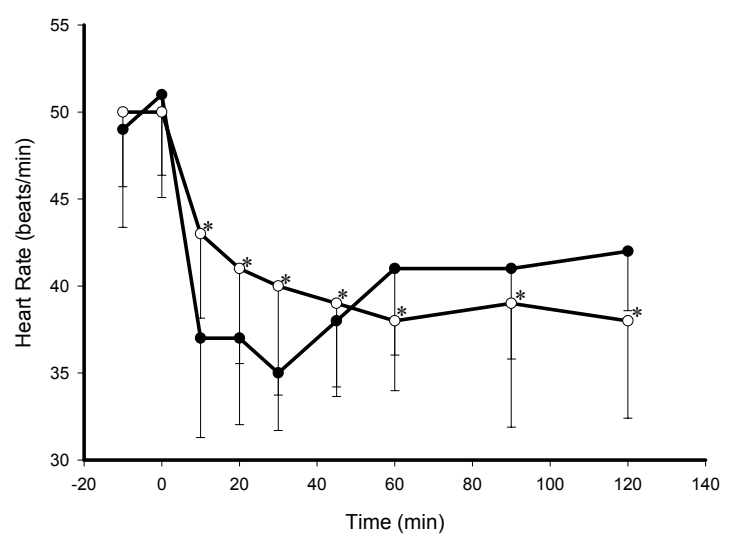

(3)

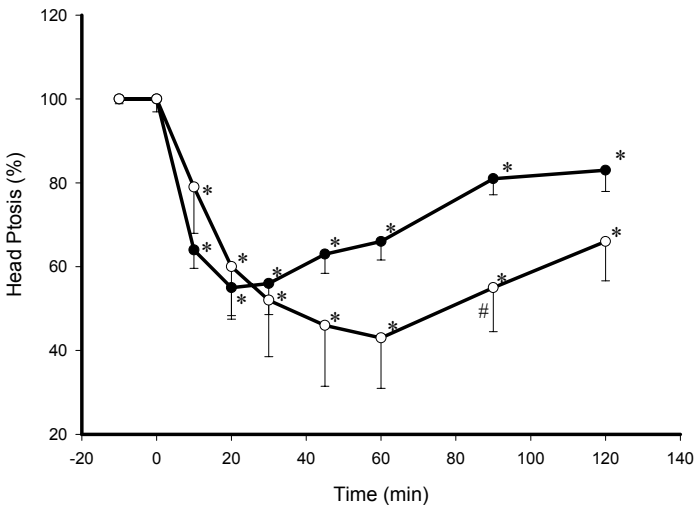

(2)

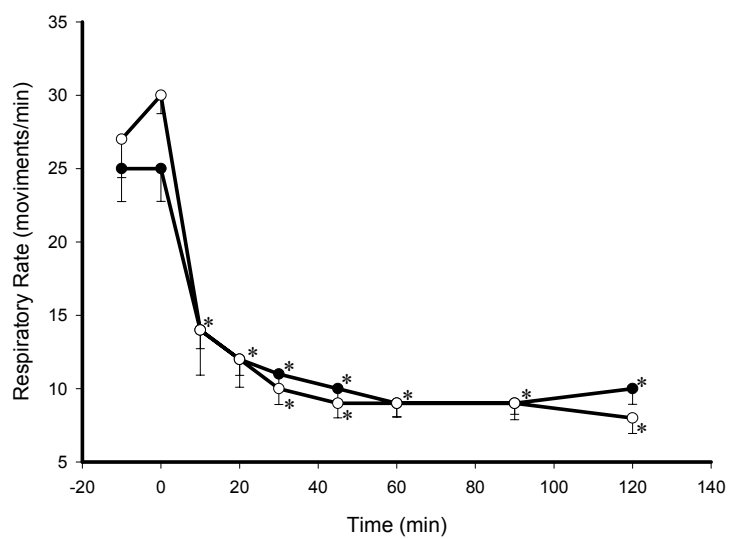

(4)

Figure 1. Behavioral and clinical effects observed after treating horses with intravenous romifidine $(60 \mathrm{mcg} / \mathrm{kg})$ or amitraz $(0.4 \mathrm{mg} / \mathrm{kg})$ administration. 1.1 : data presented as modal values; 1.2 to 1.4 : data presented as mean \pm standard error. *: significant differences comparing to basal values, Dunnett's test $(\mathrm{P} \leq 0.05)$. \#: significant differences between drugs in the determined moment, Mann-Whitney's test $(\mathrm{P} \leq 0.05)$.

HP was significantly lower after injection of romifidine or amitraz, and this effect lasted for all the testing time (120 minutes). Amitraz decreased HP more intensively at T90 $(\mathrm{P}=0.026)$. SD was significant $(\mathrm{P}<0.05)$ until 60 minutes after injection of romifidine and until 120 minutes after injection of amitraz and was more intense with romifidine at $\mathrm{T} 10(\mathrm{P}=0.026)$ and with amitraz at $\mathrm{T} 90 \quad(\mathrm{P}=0.026)$ and $\mathrm{T} 120$ $(\mathrm{P}=0.0411)$. $\mathrm{PC}$ was intense $(\mathrm{P}<0.05)$ until 90 and 120 minutes after injection of romifidine and amitraz, respectively, and it repeated what was observed to sedation at $\mathrm{T} 10$ and $\mathrm{T} 120(\mathrm{P}=0.041)$. ED occurred $(\mathrm{P}<0.05)$ until 60 and 120 minutes after administration of romifidine or amitraz, respectively, and was more intense with amitraz at T90 $(\mathrm{P}=0.0152)$. Horses presented LD $(\mathrm{P}<0.05)$ until 45 and 120 minutes after injection of romifidine and amitraz, respectively. LD was more intense with amitraz at $\mathrm{T} 45(\mathrm{P}=0.026)$ and T60 $(\mathrm{P}=0.00433)$. Administration of romifidine did not cause PD $(\mathrm{P}>0.05)$. Amitraz caused PD until 120 minutes after injection $(\mathrm{P} \leq 0.05)$.

Sedative effects of both the drugs, revealed by head ptosis and upper eyelid and lower lip drops, are attributable to general effects of alfa-2 agonists. Sedation caused by amitraz or romifidine reduced the responsive behaviors of the horses to the environment and caused 
equilibrium and posture changes, also revealing a muscle relaxation effect.

The treatment with amitraz over the upper eyelid, lower lip and penis drops, as well as head ptosis and posture changes, reveals the strong muscle relaxing effect of this substance. Besides that, horses treated with amitraz presented a wellmarked anal sphincter relaxation during their permanence in the stock, which demonstrates a stronger muscle relaxation effect to amitraz comparing it to romifidine.

Amitraz produced sedation later than romifidine, but its effect lasted longer. Head ptosis, although significant until 120 minutes for both, was more intense with amitraz at later observation periods (T90). These facts reveal that amitraz has a longlasting muscle relaxing effect when compared to romifidine, considering the testing doses.

The HR had no significant alteration after administration of romifidine $(\mathrm{P}>0.05)$ and reduced until 120 minutes after administration of amitraz $(\mathrm{P} \leq 0.05)$. Cardiac dysrhythmia was observed in five animals, from 10 to 90 minutes after romifidine injection. Both romifidine and amitraz reduced $\mathrm{RR}$ and this effect lasted until 120 minutes after injection $(\mathrm{P} \leq 0.05)$.

Amitraz reduced respiratory rate and also induced bradycardia, which reveals the intense sedative effect of this drug in the testing dose. Horses treated with romifidine presented cardiac dysrhythmia identified by auscultation, but this effect was not strong enough to affect heart rate. This could be related to the used dosage, since romifidine effects are dose-dependent. Nevertheless, it is important do emphasize that even though it had caused cardiac dysrhythmia, romifidine was able to produce sedation without affecting the heart rate.

Decrease of IM was significant $(\mathrm{P} \leq 0.05)$ until 45 and 120 minutes after injection of romifidine or amitraz, respectively. At 90 minutes, this effect was more intense with amitraz $(\mathrm{P} \leq 0.05)$. IC was reduced after administration of both drugs, and this effect lasted for the whole observation time.

Romifidine effect on ileo-cecal sphincter activity lasted longer than its effect on intestinal motion, and this is attributable to a stronger action of this drug on the large intestine. Amitraz clearly influenced the evaluated digestive system parameters, affecting peristaltic movements as much as ileo-cecal sphincter function. However, such reduction on intestinal function had not additional consequences and the horses recovered from the sedation period without presenting any difficulty. Thus, in sedative doses amitraz does not alter intestinal functions in the way that proves, it should not be used in horses. Besides, it is important to consider that fasting frequently precedes anaesthetic practices in elective procedures, which reduces the probability of occurring complications on digestive function.

Significant changes in rectal temperature were not observed after romifidine or amitraz administration. This fact, as well as the absence of penis drop with romifidine, could be related to the dosage since the effects of these drugs are dose-dependent.

Sweating occurred on cervical, ventral, inguinal and perineal regions during the testing period with both drugs. The horses also produced great volumes of urine, which is related to the effects of alfa-2 receptor agonist drugs.

\section{CONCLUSION}

Results reveal that, with the doses and excipients used in this study, romifidine and amitraz caused long-lasting sedation and decreasing in intestinal function. Amitraz sedation and posture changes had a later onset related to romifidine, but these effects lasted longer.

\section{ACKNOWLEDGEMENTS}

To Fundação de Amparo à Pesquisa do Estado de São Paulo - FAPESP (proc. 02/13569-7).

\section{REFERENCES}

CHRISTOVÃO, F.G.; ZAMUR, G.; MATAQUEIRO, M.I. et al. Sedative antinociceptive effects of romifidine and xylazine in thoroughbred mares. Arq. Bras. Med. Vet. Zootec., v.58, p.1030-1036, 2006.

CLARKE, K.W.; ENGLAND, G.W.; GOOSENS, L. Sedative and cardiovascular effects of romifidine, alone and in combination 
with butorphanol, in horses. J. Vet. Anest., v.18, p.25-30, 1991.

COSTA, L.G.; OLIBET, G.; WU, D. Acute and chronic effects of the pesticide amitraz on alpha2-adrenoceptors in the mouse brain. Toxicol. Lett., v.47, p.135-143, 1989.

FARIAS, A. Avaliação biotelemétrica e farmacológica da administração sistêmica do amitraz, em cães. 2004. 107f. Tese (Doutorado em Cirurgia Veterinária) - Faculdade de Ciências Agrárias e Veterinárias, Universidade Estadual Paulista Júlio de Mesquita Filho, Jaboticabal, SP.

FREEMAN, S.L.; ENGLAND, G.C.W. Investigation of romifidine and detomidine for the clinical sedation in horses. Vet. Rec., v. 147, p.507-511, 2000.

HAMM, D.; TURCHI, P.; JÖCHLE, W. Sedative and analgesic effects of detomidine and romifidine in horses. Vet. Rec., v.136, p.324-327, 1995.

HARKINS, J.D.; QUEIROZ-NETO, A.; MUNDY, G.D. et al. Development and characterization of an equine behaviour chamber and the effects of amitraz and detomidine on spontaneous locomotor activity. J. Vet. Pharmacol. Ther., v.20, p.396-401, 1997.

MARQUES, J.A.; TEIXEIRA-NETO, F.J.; CAMPEBELL, R.C. et al. Effects of Hyoscine$\mathrm{N}$-butylbromide given before romifidine in horses. Vet. Rec., v.142, p.166-168, 1998.

ROBERTS, M.C.; SEAWRIGHT, A.A. Experimental studies of drug-induced impaction colic in the horse. Eq. Vet. J., v.15, p.222-228, 1983.

SMITH, S.E.G. Treatment of mange in horses. Vet. Rec., v.134, p.508, 1994. 